\title{
Physiological and biochemical effects of Lantana camara L. allelochemicals on the seed germination of Avena sativa L. ${ }^{1}$
}

\author{
Diego Medeiros Gindri ${ }^{2}$, Cileide Maria Medeiros Coelho ${ }^{3}$, Virgilio Gavicho Uarrota ${ }^{4}$
}

\section{ABSTRACT}

Lantana camara (L.) is considered one of the main weeds of agricultural crops, and allelochemicals produced by this species may be a source for the development of natural herbicides. In this study, phytotoxic effects of $L$. camara aqueous extracts on seed germination and seedling growth of Avena sativa (L.) were assessed. The experimental design was completely randomized, in a 2 x 5 factorial scheme, with treatments resulting from two assays, testing five concentrations of the extract $\left(0 \%, 2.5 \%, 5.0 \%, 7.5 \%\right.$ and $\left.10 \% ; v^{-1}\right)$. During the seed germination, physiological (e.g., seed imbibition, germination and vigor) and biochemical (e.g., catalase, ascorbate peroxidase, proline, phenols, malondialdehyde and hydrogen peroxide) proprieties were evaluated. The leaf extracts of L. camara affected the response variables on $A$. sativa by reducing the germination speed index (phases I and II) and seed viability (phase III of germination), thus causing a solute leakage and increasing the production of reactive oxygen forms and, finally, lipid peroxidation. Extract concentrations above $2.5 \%$ inhibit the growth of epicotyls. Therefore, the studied allelochemicals showed potential to be exploited in the development of natural herbicides.

KEYWORDS: Antioxidant system, bioactive compounds, seed physiology, phytotoxicity.

\section{INTRODUCTION}

Allelochemicals are mainly secondary metabolites produced by plants or with microbial origin, which influence the growth or development of biological systems (IAS 1996).

Lantana camara $(\mathrm{L}$.$) , as a perennial aromatic$ shrub of the Verbenaceae family, is considered

\section{RESUMO \\ Efeitos fisiológicos e bioquímicos \\ de aleloquímicos de Lantana camara L. \\ na germinação de sementes de Avena sativa $\mathrm{L}$.}

Lantana camara (L.) é considerada uma das principais plantas invasoras de culturas agrícolas, e aleloquímicos produzidos por essa espécie podem ser fonte para o desenvolvimento de herbicidas naturais. Avaliaram-se efeitos fitotóxicos de extratos aquosos de $L$. camara sobre a germinação de sementes e o crescimento de plântulas de Avena sativa (L.). O delineamento experimental foi completamente randomizado, em esquema fatorial $2 \times 5$, com tratamentos resultantes de dois ensaios, testando-se cinco concentrações do extrato $\left(0 \%, 2,5 \%, 5,0 \%, 7,5 \%\right.$ e $10 \%$; vv $\left.{ }^{-1}\right)$. Durante a germinação das sementes, foram avaliadas propriedades fisiológicas (e.g., embebição, germinação e vigor de sementes) e bioquímicas (e.g., catalase, ascorbato peroxidase, prolina, fenóis, malondialdeído e peróxido de hidrogênio). Os extratos foliares de L. camara afetaram as variáveis respostas em $A$. sativa, reduzindo o índice de velocidade de germinação (fases I e II) e a viabilidade das sementes (fase III da germinação), provocando, então, vazamento de soluto e aumento da produção de formas reativas de oxigênio e, finalmente, peroxidação lipídica. Concentrações de extrato acima de 2,5\% inibem o crescimento de epicótilos. Portanto, os aleloquímicos estudados mostraram potencial para exploração no desenvolvimento de herbicidas naturais.

PALAVRAS-CHAVE: Sistema antioxidante, compostos bioativos, fisiologia de sementes, fitotoxicidade.

worldwide as a major invasive plant (Chengxu et al. 2011).

Among the metabolites found in L. camara, 1,8-cineol, $\beta$-pinene, dipentene, lantadene $\mathrm{A}$ and lantadene $\mathrm{D}$ have been cited as important intermediate sources for herbicide development (Kegge \& Pierik 2010, Mishra 2015, Latif et al. 2017, Gindri et al. 2020).

\footnotetext{
${ }^{1}$ Received: Mar. 16, 2020. Accepted: May 29, 2020. Published: July 27, 2020. DOI: 10.1590/1983-40632020v5062546.

${ }_{2}^{2}$ Companhia Integrada de Desenvolvimento Agrícola de Santa Catarina, Departamento de Defesa Vegetal, Lages, SC, Brasil. E-mail/ORCID: diegogindri@gmail.com/0000-0002-3930-287X.

${ }^{3}$ Universidade do Estado de Santa Catarina, Centro de Ciências Agroveterinárias, Departamento de Agronomia, Lages, SC, Brasil.E-mail/ORCID: cileidecoelho@yahoo.com.br/0000-0001-9528-7371.

${ }^{4}$ Pontificia Universidad Católica de Valparaiso, Escuela de Agronomia, La Palma, Quillota, Chile. E-mail/ORCID: uaceleste@yahoo.com.br/0000-0002-2974-1625.
} 
Allelopathic compounds (e.g., phenolics, terpenoids, alkaloids and their derivatives) are reported to inhibit seed germination and reduce the germination speed index and seedling growth (AbuRomman et al. 2010, Hussain \& Reigosa 2011). Such phytotoxity effects occur because of their action on cellular degradation processes through the production of reactive oxygen species, resulting in cellular oxidative stress (Bogatek \& Gniazdowska 2007, Qian et al. 2009).

The mechanisms that define how the allelochemicals of $L$. camara act have not been described yet. The response to alelochemicals leads to the induction of adaptive changes in the biochemical and gene expression of plants, such as induction of the enzymatic and non-enzymatic antioxidant defense system. The ability of the cell to cope with the oxidative stress produced by alellochemicals will largely depend on the endogenous free radical scavenging capacity of the species (Mittler 2017).

In general, abiotic and biotic stresses will induce perturbations in the fruit cellular homeostasis, which will then result in an increased generation of reactive oxygen species. When the free radicals scavenging capacity exceeds the endogenous scavenging, reactive oxygen species interact with sensors that will initiate cascade reactions and also up-regulation of transcription factors (Toivonen \& Hodges 2011), resulting in oxidative stress.

Studies on enzymatic activity, free radical content, cell membrane system integrity and other tests routinely used for seed vigor and germination may be important tools in elucidating the action mechanisms of allelopathic compounds. Moreover, despite the extensive literature about the effects of $L$. camara allelochemicals, studies regarding such effects on Avena sativa are still scarce. In this research, it was hypothesized that L. camara extracts affect physiological and biochemical proprieties of A. sativa seed germination and, therefore, have a potential to be used in the development of natural herbicides. This study aimed to evaluate such effects.

\section{MATERIAL AND METHODS}

Commercial seeds of $A$. sativa were obtained from the seed laboratory of the Universidade do Estado de Santa Catarina and stored in a dry and cold chamber $(50 \pm 5 \%$ relative humidity and $8 \pm 2{ }^{\circ} \mathrm{C}$ ), until analysis, and $L$. camara leaves were collected from wild plants in the city of Lages, Santa Catarina state, Brazil. Leaves were then washed using distilled water and dried in an oven with air circulation at $40^{\circ} \mathrm{C}$, for $72 \mathrm{~h}$. After drying, the leaves were shredded and stored in a dry and cold chamber $\left(50 \pm 5 \%\right.$ relative humidity and $\left.8 \pm 2{ }^{\circ} \mathrm{C}\right)$, until analysis. The extracts were prepared by mixing $10 \mathrm{~g}$ of leaf powder in $90 \mathrm{~mL}$ of distilled water $\left(25^{\circ} \mathrm{C}\right.$, for $24 \mathrm{~h}$ ). The mixture was filtered and then centrifuged at 3,600 rpm, for $10 \mathrm{~min}$. The resulting supernatant (crude extract) was diluted in distilled water to obtain the different tested extract concentrations: $0 \%, 2.5 \%$, $5.0 \%, 7.5 \%$ and $10 \%\left(\mathrm{vv}^{-1}\right)$.

For the viability and vigor tests, four replications of 25 seeds were sown in acrylic boxes $(12 \mathrm{~cm} \times 12 \mathrm{~cm})$, on three sheets of germitest paper moistened 2.5 times the weight of the dry paper with water and extracts in the different concentrations. The boxes were transferred to a biochemical oxygen demand (BOD) chamber at $25^{\circ} \mathrm{C}$ and 12-h photoperiod.

The samples for seed imbibition assessment were prepared in the same way; but, after the seed preparation at each different time $(0,3,6,9,12,18$, 24, 36, 48, 72 and 96 h), two samples of 25 seeds were kiln dried $\left(105^{\circ} \mathrm{C}\right.$, for $\left.24 \mathrm{~h}\right)$ to determine the moisture. The imbibition curve was obtained by using the difference of humidity between the times.

For seed germination, after preparation, the seeds remained in water (control) or in each one of the L. camara extract concentrations, until seven days after sowing. Also, in the beginning of the germination phase III (root protrusion), a part of the seeds previously exposed only to water at the germination phases I and II were transferred to boxes containing the extract at different concentrations; and those previously exposed to the extract were transferred to boxes with water. The results were expressed as percentage of normal seedlings.

The germination speed index (GSI) was evaluated by counting, every $12 \mathrm{~h}$ of the assay, the total number of germinated seeds (root protrusion of $2 \mathrm{~mm}$ ), until a constant number of germinated seeds. Thus, it was calculated according to following equation: GSI $(\%)=\sum\left[\mathrm{G}_{\mathrm{S} 1} / \mathrm{C}_{1}\right)+\left(\mathrm{G}_{\mathrm{S} 2} / \mathrm{C}_{2}\right)+\ldots+$ $\left.\left(\mathrm{G}_{\mathrm{Sn}} / \mathrm{C}_{\mathrm{n}}\right)\right] \times 100$, where: $\mathrm{C}_{1}, \mathrm{C}_{2} \ldots \mathrm{C}_{\mathrm{n}}$ represent the first, second and $\mathrm{n}^{\text {th }}$ seed counts, and $\mathrm{G}_{\mathrm{S} 1}, \mathrm{G}_{\mathrm{S} 2} \ldots \mathrm{G}_{\mathrm{Sn}}$ are the respective numbers of germinated seeds at these counts (Souza-Filho et al. 2010).

To evaluate the vigor by electrical conductivity, four replications of 50 seeds were previously 
weighed and soaked $(1 \mathrm{~h})$ in the different extract concentrations $(0 \%, 2.5 \%, 5.0 \%, 7.5 \%$ and $10 \%)$. After imbibition, the seeds were washed in distilled water, transferred to a cylindrical flat bottom beaker containing distilled water $(50 \mathrm{~mL})$ and stored in a BOD chamber $\left(20^{\circ} \mathrm{C} / 24 \mathrm{~h}\right)$. The electrical conductivity was evaluated after $24 \mathrm{~h}$, with results expressed as $\mu \mathrm{S} \mathrm{cm}^{-1} \mathrm{~g}^{-1}$ of seeds (Vieira \& Carvalho 1994).

In the evaluation of vigor by initial seedling growth, after preparation, the hypocotyl and root length, as well as the presence of secondary roots, were then measured. The results were expressed as growth inhibition rate and presence of secondary roots rate (Nakagawa 1999).

The biochemical properties measured in this study were contents of malondialdehyde (MDA) and hydrogen peroxide $\left(\mathrm{H}_{2} \mathrm{O}_{2}\right)$, enzymatic activities of catalase and ascorbate peroxidase, as well as proline and total phenolic compounds contents.

For the MDA and $\mathrm{H}_{2} \mathrm{O}_{2}$ determination, seed samples $(200 \mathrm{mg})$ were macerated in liquid nitrogen and homogenized in $2 \mathrm{~mL}$ of trichloroacetic acid (TCA) $0.1 \%$. The homogenate was centrifuged at $3,600 \mathrm{rpm}$, for $15 \mathrm{~min}$, and the supernatant recovered. For MDA, the assay mixture consisted of $20 \%$ of TCA and $0.5 \%$ of thiobarbituric acid. The reaction was performed by mixing $250 \mu \mathrm{L}$ of supernatant and $1 \mathrm{~mL}$ of the mixture, followed by incubation in water bath $\left(95^{\circ} \mathrm{C}\right)$ for $30 \mathrm{~min}$. Then, the reaction was stopped on ice $(10 \mathrm{~min})$. The samples were left to stand at room temperature for $10 \mathrm{~min}$, and absorbance was measured using a spectrophotometer at $600 \mathrm{~nm}$ and $535 \mathrm{~nm}$. The results were expressed as $\mu \mathrm{mol} \mathrm{g}{ }^{-1}$ of fresh mass (Heath \& Packer 1968).

The reaction mixture for $\mathrm{H}_{2} \mathrm{O}_{2}$ consisted of $200 \mu \mathrm{L}$ of supernatant, $800 \mu \mathrm{L}$ of potassium iodide and $200 \mu \mathrm{L}$ of phosphate buffer $(0.1 \mathrm{M}$; $\mathrm{pH} 7.5)$, followed by incubation on ice during $1 \mathrm{~h}$. Then, the samples were left to stand at room temperature for $5 \mathrm{~min}$ and absorbance readings were recorded using a spectrophotometer at $390 \mathrm{~nm}$, with results expressed as nmol g-1 of fresh mass (Alexieva et al. 2001). Both assays were performed with three replicates.

To enzyme extraction and protein determination, fresh samples collected at 24, 48, 72 and $120 \mathrm{~h}$ of germination were macerated in a mortar using liquid nitrogen, and $1 \mathrm{~g}$ of sample was homogenized with $1.8 \mathrm{~mL}$ of $100 \mathrm{mM}$ potassium phosphate buffer $(\mathrm{pH}$ 7.8) containing $0.1 \mathrm{mM}$ of ethylenediaminetetraacetic acid (EDTA) and $20 \%$ of polyvinylpolypyrrolidone (PVPP). The extract was centrifuged at $13,000 \mathrm{~g} / 20 \mathrm{~min}$ $\left(4^{\circ} \mathrm{C}\right)$ and the supernatant was used to determine the enzymatic activities (Bradford 1976).

The catalase activity (CAT - EC 1.11.1.6) was assayed spectrophotometrically at $25^{\circ} \mathrm{C}$, in a reaction mixture containing $1 \mathrm{~mL}$ of $100 \mathrm{mM}$ potassium phosphate buffer ( $\mathrm{pH} 7.5$ ) plus $2.5 \mu \mathrm{L}$ of $\mathrm{H}_{2} \mathrm{O}_{2}(25 \%$ solution), prepared immediately before its use. The reaction was started by the addition of $25 \mu \mathrm{L}$ of plant extract, and the catalase activity was monitored by $\mathrm{H}_{2} \mathrm{O}_{2}$ degradation at $240 \mathrm{~nm}$, over a 1-min period (Azevedo et al. 1988).

The ascorbate peroxidase activity (APX - EC 1.11.1.11) was assayed by monitoring the oxidation rate of ascorbate during $2 \mathrm{~min}$ at $290 \mathrm{~nm}(\varepsilon=2.80 \mathrm{x}$ $\left.103 \mathrm{M}^{-1} \mathrm{~cm}^{-1}\right)$. The reaction mixture consisted of $13 \mathrm{~mL}$ of $100 \mathrm{mM}$ potassium phosphate buffer $(\mathrm{pH}$ 7.0), $2 \mathrm{~mL}$ of $0.5 \mathrm{mM}$ ascorbic acid and $2 \mathrm{~mL}$ of $1 \mathrm{mM}$ EDTA. The reaction was started by adding $1,780 \mu \mathrm{L}$ of the reaction medium, $200 \mu \mathrm{L}$ of $0.1 \mathrm{mM} \mathrm{H}_{2} \mathrm{O}_{2}$ and $20 \mu \mathrm{L}$ of the enzyme extract. The results, such as for

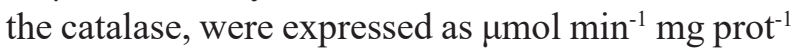
(Nakano \& Asada 1981).

To quantify the proline content, seed samples $(0.3 \mathrm{mg})$ were macerated in liquid nitrogen and homogenized in $6 \mathrm{~mL}$ of sulfosalicylic acid (3\%). The homogenate was centrifuged at 3,600 rpm for $30 \mathrm{~min}$ and the supernatant was used. Proline was determined by mixing $2 \mathrm{~mL}$ of the supernatant, $2 \mathrm{~mL}$ of an acidic ninhydrin solution and $2 \mathrm{~mL}$ of glacial acetic acid. The reaction mixture was incubated in water bath $\left(100{ }^{\circ} \mathrm{C}\right.$, for $\left.60 \mathrm{~min}\right)$ and left to stand on ice for $10 \mathrm{~min}$. After that, $2 \mathrm{~mL}$ of toluene were added and the mixture rested for $20 \mathrm{~min}$ at room temperature, for phase separation. The upper phase was collected and absorbance readings were performed spectrophotometrically at $520 \mathrm{~nm}$. The results were expressed as $\mu \mathrm{mol} \mathrm{g}^{-1}$ of fresh mass (Bates et al. 1973).

The total phenolic compounds were similarly quantified from the seed samples $(0.3 \mathrm{mg})$, also macerated in liquid nitrogen, homogenized in $3 \mathrm{~mL}$ of acidified methanol $(1 \mathrm{~mL}$ of hydrochloric acid $+100 \mathrm{~mL}$ of methanol at $80 \%$ ) and centrifuged $(3,600 \mathrm{rpm}$, for $30 \mathrm{~min})$. Thus, the supernatant $(100 \mu \mathrm{L})$ was mixed with $700 \mu \mathrm{L}$ of Folin-Ciocalteau $(0.25 \mathrm{M})$ and incubated in the dark for $3 \mathrm{~min}$. Then, $700 \mu \mathrm{L}$ of $\mathrm{Na}_{2} \mathrm{CO}_{3}(0.2 \mathrm{M})$ were added and incubated in the dark for $30 \mathrm{~min}$. The absorbance readings 
were carried out spectrophotometrically at $725 \mathrm{~nm}$. The results were expressed as mg GAE (gallic acid equivalent) $\mathrm{g}^{-1}$ of fresh mass (Folin \& Ciocalteu 1927).

The data for all variables were summarized, subjected to normality (Shapiro-Wilk) and homogeneity (Levene) tests, and analyses of variance (Anova) were conducted. Two independent analyses were performed, because the statistical results showed no significant differences between the experiments. The results are presented as mean and standard deviation of all replicates, and the response variables were submitted to regression analysis. The best models displayed in graphics were selected according to the higher R-squared and lower Akaike Information Criterium (AIC). All statistical analyses were performed by the R software (R Core Team 2019).

\section{RESULTS AND DISCUSSION}

The reduction of water potential during seed germination may result in lower germination rates, or even its inhibition (Cardoso 2004). Under full water availability, the imbibition of $A$. sativa seeds presents a three-phase curve. In the phase I, the water content in the seed increases rapidly, what is followed by a stabilization in the phase II, until the protrusion of the radicle, thus starting the phase III, with another increase in water content due to the growth of the embryo (Bewley et al. 2013).

The three-phase seed germination pattern was observed for all treatments in the imbibition curve, with a rapid absorption of water up to $9 \mathrm{~h}$, a phase of low water absorption between $9 \mathrm{~h}$ and $36 \mathrm{~h}$, and a recovery in the water absorption rate after $48 \mathrm{~h}$. The results indicate that the osmotic potential of aqueous solutions of $L$. camara leaves did not interfere in the water absorption of the seeds.

The germination of A. sativa seeds, expressed as percentage of normal seedlings, was not affected by the aqueous extract concentrations of L. camara leaves, when exposed to the phases I and II of germination (Figure 1A). However, the germination of the seeds, when they were exposed to the extract in the phase III, was significantly affected at all concentrations of the extract (Figure 1B). In the phase III, the seed germination from $78 \pm 5 \%$ in the control treatment was reduced to $54 \% \pm 1,43 \% \pm 12$, $14 \% \pm 8$ and $6 \% \pm 6$, respectively, at aqueous extract concentrations of $2.5 \%, 5 \%, 7.5 \%$ and
$10 \%\left(\mathrm{vv}^{-1}\right)$. Also, when $A$. sativa seeds were exposed to the extract during all the germination phases (I, II and III), there was a reduction of the percentage of normal seedlings for all extract concentrations (Figure 1C). In these treatments, because of the longer exposure time to the extract (from phase I to III), there was a greater damage to seed germination. The seed germination was completely inhibited at the aqueous extract concentration of $10 \%\left(\mathrm{vv}^{-1}\right)$.
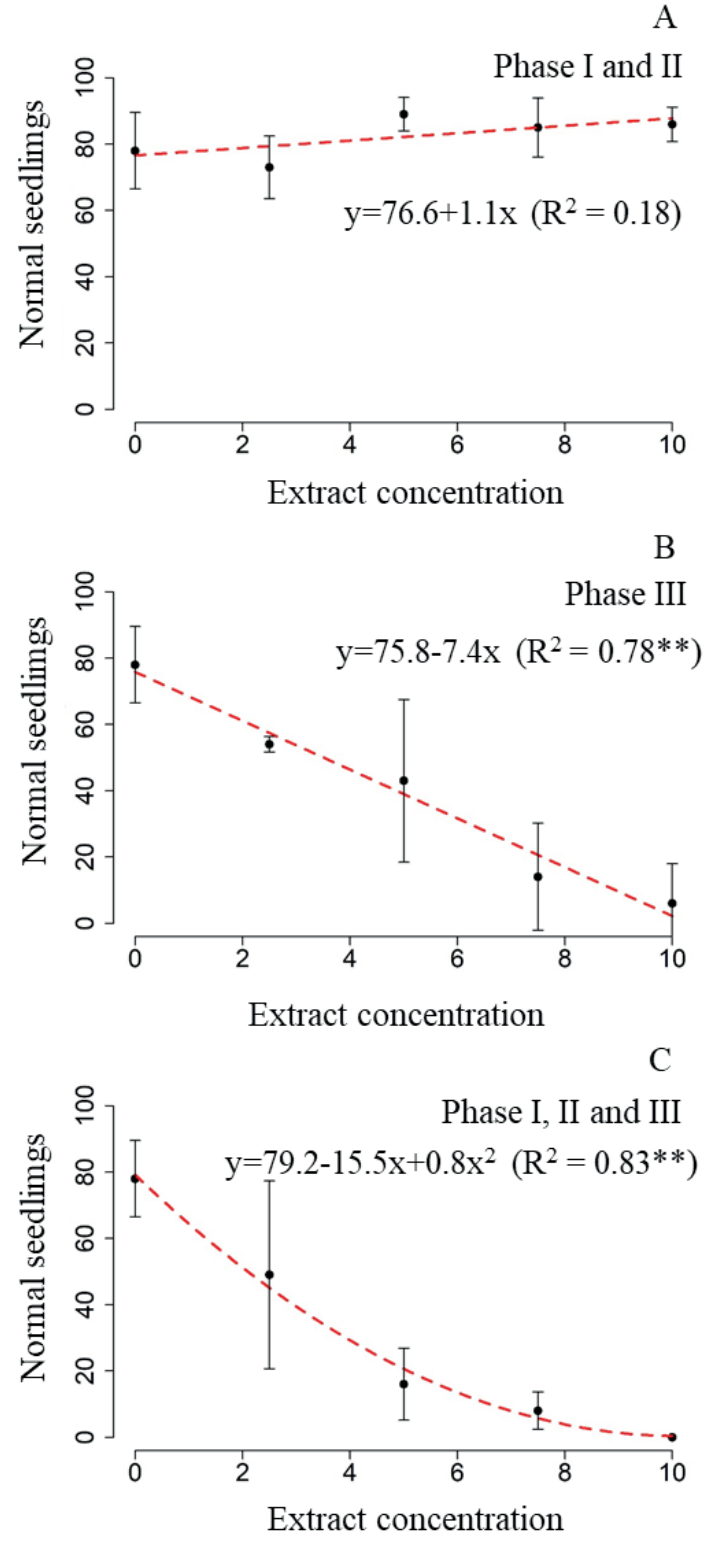

Figure 1. Regressions for the percentage of normal seedlings, when Avena sativa seeds were exposed to the Lantana camara extract, at different concentrations $\left(\% ; \mathrm{vV}^{-1}\right)$, in the germination phases I and II (A), III (B) or during the three phases $(\mathrm{C})$. The bars for observed points are the mean standard deviations. 
According to Kupidlowska et al. (1994), the phyto-chemical coumarin found in L. camara leaves by Yi et al. (2006) causes necrosis and inhibition of root growth in seedlings. Atrophied and necrotic roots were the main anomalies found in seeds exposed to these phytochemicals, although the phytotoxic damages of the extract to the seed metabolism were not sufficient to promote the death of the seedlings.

DNA synthesis, mitotic divisions and mobilization of reserve substances occur after the embryo growth begins, in the phase III of germination (Cardoso 2004, Bewley et al. 2013). The results indicate that the phytochemicals of $L$. camara present in the extract interfere in these metabolic processes.

The aqueous extract of $L$. camara caused a reduction in the germination speed index at all tested concentrations (Figure 2A). The germination speed index values were reduced from $13.8 \% \pm 0.3$ to $11.7 \% \pm 0.8,10.5 \% \pm 0.5,9.17 \% \pm 0.3$ and $8.4 \% \pm 0.2$, respectively, at the concentrations of $2.5 \%, 5 \%, 7.5 \%$ and $10 \%$. The delay in the radicle emission may be explained by the interference in the growth of the allelochemicals present in the extract, such as reactivation of mitochondrial Krebs cycle enzymes and oxidative phosphorylation, as well as protein synthesis from substrates (enzymes, mRNA, etc.), that occur during the germination phases I and II (Cardoso 2004, Bewley et al. 2013).

Allelochemicals may rapidly depolarize the cell membrane, increasing the permeability and inducing lipid peroxidation (Yu et al. 2003). Previous reports have shown that the increase of electrolyte flow may be one of the consequences of membrane integrity damage (Poonpaiboonpipat et al. 2013). A significant seed solute leakage was observed

A

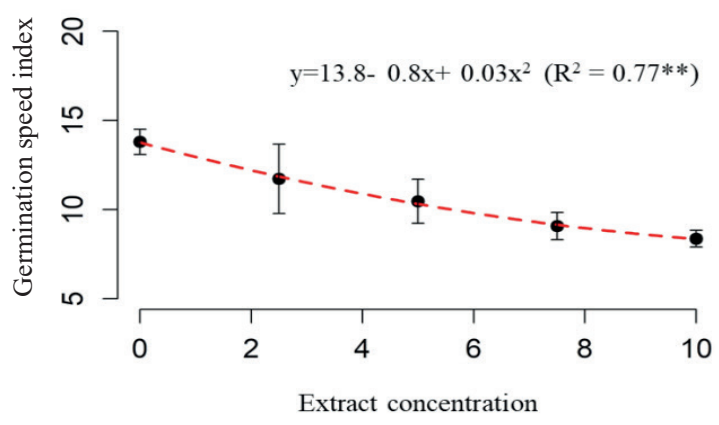

when exposed to the extract. The solute leakage increased with the increase of extract concentration (Figure 2B); hence, it may be stated that there is damage to the repair system of cell membranes during seed imbibition, caused by the allelochemicals present in the extract. Aumonde et al. (2013) also reported a higher release of lettuce seed electrolytes with an increase in the concentration of the aqueous extract of Philodendron bipinnatifidum.

The exposure of the aqueous extract of L. camara during seed germination at the phases I and II did not affect the epicotyl and root development of the A. sativa seedlings. The seeds submitted to the extract during the phase III of germination had their growth negatively affected. The extracts reduced the epicotyl growth by $57 \%, 66 \%, 84 \%$ and $90 \%$ (Figure $3 \mathrm{~A}$ ) and root growth by $28 \%, 43 \%, 57 \%$ and $62 \%$ (Figure $3 \mathrm{~B}$ ), respectively, at concentrations of $2.5 \%, 5 \%, 7.5 \%$ and $10 \%$. The exposure of the seeds to the extract during all phases of seed germination (I, II and III) caused the greatest damage to the epicotyl and root growth, reaching $99 \%$ of inhibition. The reductions reached $57 \%, 81 \%, 89 \%$ and $99 \%$ for epicotyls (Figure 3C) and $41 \%, 58 \%$, $74 \%$ and $99 \%$ for roots (Figure 3D), respectively, at concentrations of $2.5 \%, 5 \%, 7.5 \%$ and $10 \%$.

Seedling growth is known to depend on DNA synthesis, mitotic divisions and seed reserve mobilization (Cardoso 2004, Bewley et al. 2013). Mitotic divisions can be reduced by the action of allelochemicals (Ladhari et al. 2014), compromising the normal plant development. Romagni et al. (2000) reported that the compound 1,8-cineol is present as a mitotic index and root growth reducer. The phytochemical 1,8-cineol is present in L. camara

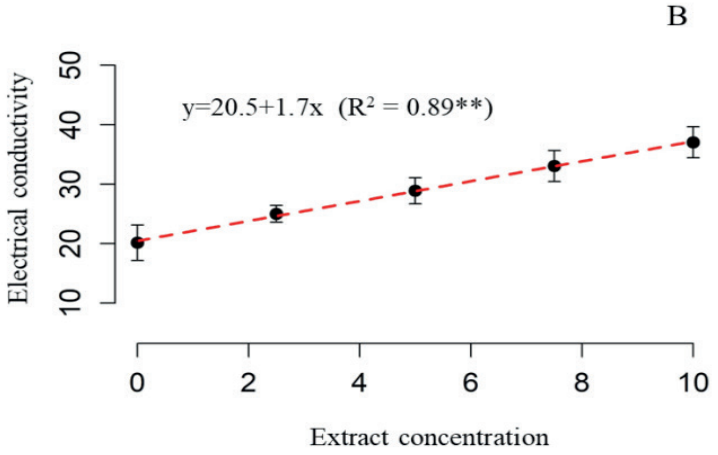

Figure 2. Regressions for the germination speed index (A; \%) and electrical conductivity $\left(\mathrm{B} ; \mu \mathrm{S} \mathrm{cm}{ }^{-1} \mathrm{~g}^{-1}\right)$ of Avena sativa seeds, as a function of Lantana camara extract at different concentrations $\left(\% ; \mathrm{vv}^{-1}\right)$. The bars for observed points are the mean standard deviations. 
A

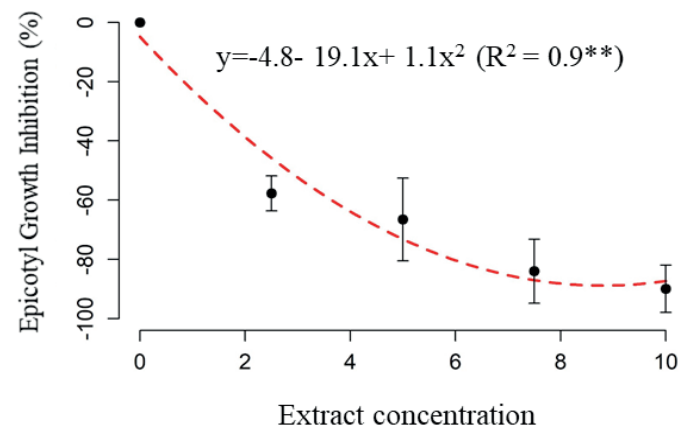

$\mathrm{C}$

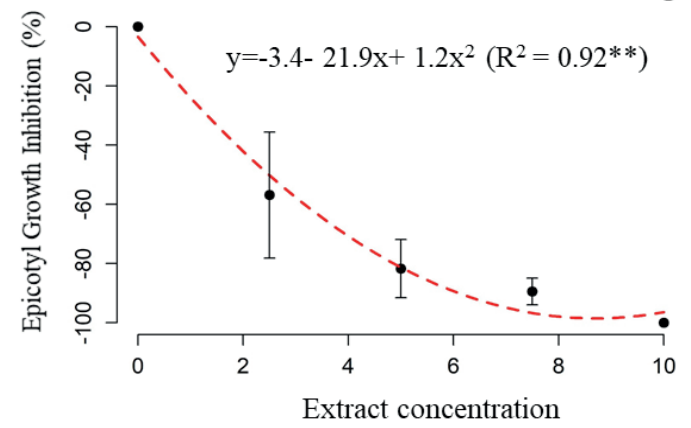

B

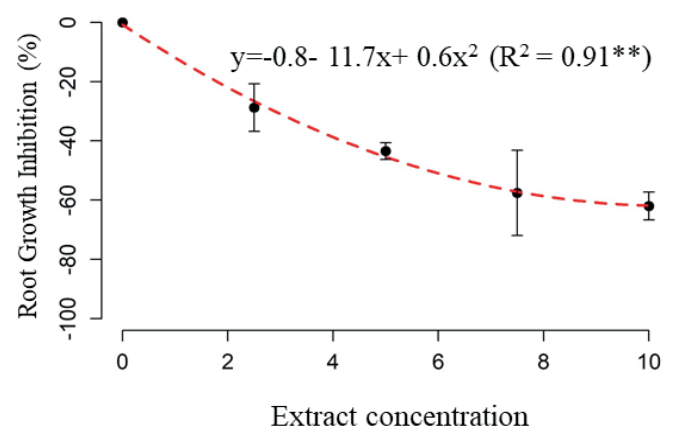

$\mathrm{D}$

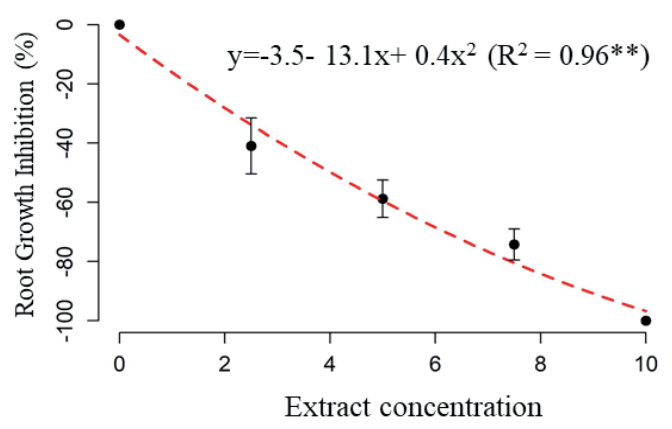

Figure 3. Regressions for the epicotyl and root growth inhibition at the phase III (A-B) and phases I, II and III (C-D) of germination of Avena sativa seeds, as a function of Lantana camara extract at different concentrations $\left(\% ; \mathrm{vV}^{-1}\right)$. The bars for observed points are the mean standard deviations.

extracts (Singh et al. 2012) and may be involved in the phytotoxic action of the aqueous extract of $L$. camara leaves in A. sativa seedlings. Kenany \& Darier (2013) did not identify the compounds involved; however, they reported that the extract of L. camara leaves is able to inhibit the root and stem elongation during the seed germination of Phalaris minor and Sorghum bicolor.

The malondialdehyde (MDA) levels, at 24 and 48 h of germination, were not affected by the exposure to the allelochemicals in the extract concentration of $5 \%\left(\mathrm{vv}^{-1}\right)$. After $48 \mathrm{~h}$ of germination, the MDA levels remained stable in the control; however, there was an increase in the MDA levels at $72 \mathrm{~h}$ of germination of the seeds exposed to phytochemicals $\left(3.0 \pm 0.1 \mu \mathrm{mol} \mathrm{g}{ }^{-1}\right)$, and they were also high at $120 \mathrm{~h}$ of germination $\left(2.7 \pm 0.1 \mu \mathrm{mol} \mathrm{g}{ }^{-1}\right)$ (Figure 4A). When the seeds were removed from the water and exposed to the extract within $48 \mathrm{~h}$ of germination, there was a large increase in the MDA levels at $72 \mathrm{~h}$ of germination $\left(3.6 \pm 0.1 \mu \mathrm{mol} \mathrm{g}{ }^{-1}\right)$, indicating a phytotoxic action. Conversely, the seeds removed from the extract within $48 \mathrm{~h}$ of germination had reduced MDA levels by $72 \mathrm{~h}$ of germination $\left(1.8 \pm 0.2 \mu \mathrm{mol} \mathrm{g}{ }^{-1}\right)$. The phase III of germination is more sensitive to allelochemicals, as observed by the higher levels of oxidative stress markers. Increases in the MDA levels related to phytochemical stress are also reported in lettuce (Ladhari et al. 2014), soybean (Haddadchi \& Gerivani 2009), mustard (Oracz et al. 2007), maize, pea and radish (Gmerek \& Politycka 2011). Gmerek \& Politycka (2011) attribute the lipid peroxidation to the phytochemicals ferulic and p-coumaric acids present in L. camara extracts (Yi et al. 2006).

Malondialdehyde (MDA) is one of the final products of polyunsaturated fatty acids peroxidation in the cells. The MDA content is commonly known as a marker of oxidative stress (Gawel et al. 2004). Kurek et al. (2019) reported that the genomic integrity considerably affects the seed viability and vigor. Quinones and phenols (groups of allelochemical compounds) are thought to have a toxic effect, because of their ability to form semiquinone radicals that donate electrons to molecular oxygen, forming reactive oxygen species (Hammond-Kosak \& Jones 1996).

The $\mathrm{H}_{2} \mathrm{O}_{2}$ levels increased throughout the period of seed germination; however, there were 
A

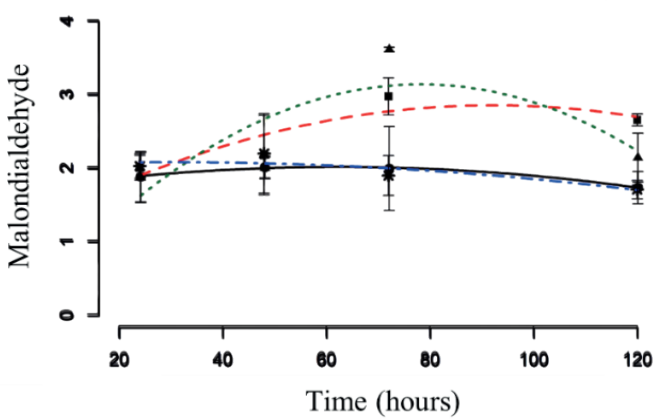

$$
\begin{array}{cc}
-0:\left(\mathrm{R}^{2}=0.12^{\mathrm{ns}}\right) & ----5:\left(\mathrm{R}^{2}=0.54^{*}\right) \\
\mathrm{y}=1.7+0.1 \mathrm{x}-0.00008 \mathrm{x}^{2} & \mathrm{y}=1.1+0.04 \mathrm{x}-0.002 \mathrm{x}^{2} \\
-0 \_5:\left(\mathrm{R}^{2}=0.57^{*}\right) & ---5 \_0:\left(\mathrm{R}^{2}=0.24^{\mathrm{ns}}\right) \\
\mathrm{y}=0.004+0.08 \mathrm{x}-0.0005 \mathrm{x}^{2} & \mathrm{y}=2.0+0.003 \mathrm{x}-0.00005 \mathrm{x}^{2}
\end{array}
$$

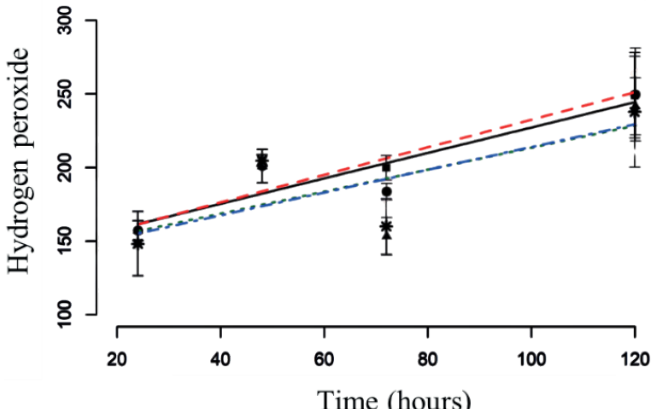

$$
\begin{array}{cc}
0:\left(\mathrm{R}^{2}=0.70^{* *}\right) & ---5:\left(\mathrm{R}^{2}=0.73^{* *}\right) \\
\mathrm{y}=140.7+0.9 \mathrm{x} & \mathrm{y}=138.8+0.9 \mathrm{x} \\
-0 \_5:\left(\mathrm{R}^{2}=0.49^{*}\right) & ----5 \_0:\left(\mathrm{R}^{2}=0.45^{*}\right) \\
\mathrm{y}=139.0+0.7 \mathrm{x} & \mathrm{y}=137.0+0.8 \mathrm{x}
\end{array}
$$

Figure 4. Regressions for malondialdehyde ( $\mathrm{A} ; \mu \mathrm{mol} \mathrm{g} \mathrm{g}^{-1}$ of fresh mass) and hydrogen peroxide (B; nmol g-1) contents, during the germination period (in hours) of Avena sativa seeds, when kept in water (0) or exposed to Lantana camara extract at the concentration of $5 \%\left(\mathrm{vv}^{-1}\right)(5)$, and with induction $\left(0 \_5\right)$ or removal $\left(5 \_0\right)$ of the phytotoxic stress. The bars for observed points are the mean standard deviations.

no differences between the control and the seeds exposed to the extract (Figure 4B). Contrary to our results, allelopathic metabolites increase the $\mathrm{H}_{2} \mathrm{O}_{2}$ levels in some plant species, such as Sinapis alba (Oracz et al. 2007) and Chlorella vulgaris (Qian et al. 2009). The non-increase of $\mathrm{H}_{2} \mathrm{O}_{2}$ levels may be related to an efficient antioxidant defense system of A. sativa.

Lower levels of catalase activity, between 48 and $120 \mathrm{~h}$ of germination, were observed in the seeds exposed to the extract $\left(5 \% ; \mathrm{vv}^{-1}\right)$, when compared to the control $\left(0 \% ; \mathrm{vV}^{-1}\right)$ (Figure $\left.5 \mathrm{~A}\right)$. The reduction in the levels of catalase enzyme in the seeds exposed to the extract is possibly related to the action of the enzyme in neutralizing reactive oxygen species, accumulated by the phytotoxic effect of the extract.

When the seeds were removed from the water $\left(0 \% ; \mathrm{vv}^{-1}\right)$ and exposed to the phytotoxic extract at the concentration of $5 \%\left(\mathrm{vV}^{-1}\right)$ (treatment denoted as "0_5"), a high increase in the catalase activity
A

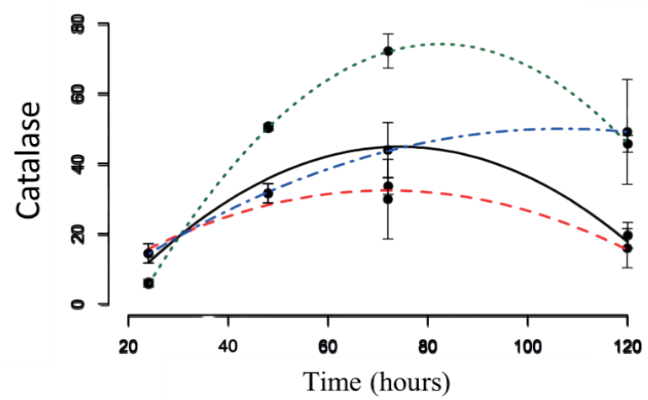

$$
\begin{array}{cc}
0:\left(\mathrm{R}^{2}=0.64^{* *}\right) & ---5:\left(\mathrm{R}^{2}=0.62^{*}\right) \\
\mathrm{y}=-27.1+1.9 \mathrm{x}-0.01 \mathrm{x}^{2} & \mathrm{y}=-5.3+1.0 \mathrm{x}-0.007 \mathrm{x}^{2} \\
-0.5:\left(\mathrm{R}^{2}=0.99^{* *}\right) & ---50:\left(\mathrm{R}^{2}=0.78^{* *}\right) \\
\mathrm{y}=-61.9+3.3 \mathrm{x}-0.02 \mathrm{x}^{2} & \mathrm{y}=-9.4+1.1 \mathrm{x}-0.005 \mathrm{x}^{2}
\end{array}
$$

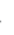

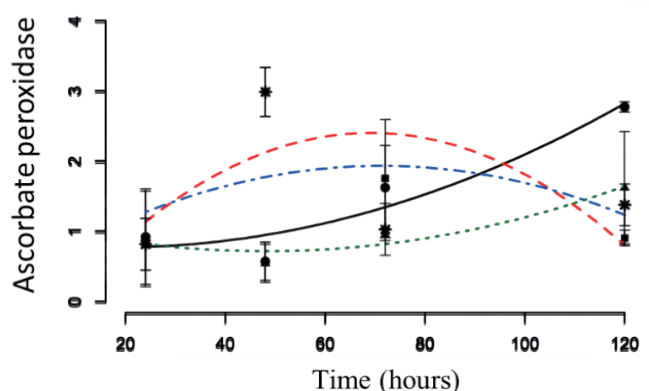

$$
\begin{array}{ll}
-0:\left(R^{2}=0.75^{* *}\right) & ---5:\left(R^{2}=0.48^{*}\right) \\
y=0.8-0.007 x+0.0002 x^{2} & y=-0.6+0.1 x-0.0006 x^{2} \\
--0 ~ 5:\left(R^{2}=0.40^{n s}\right) & ---5 \_0:\left(R^{2}=0.12^{n s}\right) \\
y=1.2-0.02 x+0.0002 x^{2} & y=0.4+0.04 x-0.0003 x^{2}
\end{array}
$$

Figure 5. Regressions for the enzymatic activities ( $\mu \mathrm{mol} \mathrm{min} \mathrm{mg}^{-1} \mathrm{mg} \operatorname{pot}^{-1}$ ) of catalase $(\mathrm{A})$ and ascorbate peroxidase (B), during the germination period (in hours) of Avena sativa seeds, when kept in water (0) or exposed to Lantana camara extract at the concentration of $5 \%\left(\mathrm{vv}^{-1}\right)(5)$, and with induction $\left(0 \_5\right)$ or removal $\left(5 \_0\right)$ of the phytotoxic stress. The bars for observed points are the mean standard deviations. 
was observed, with a subsequent rapid reduction (Figure 5A). This indicates a metabolic response of reactive oxygen species for neutralization. In seeds removed from the phytotoxic stress (extract at the concentration of $5 \%$ ) to water, here denoted as " 5 _0", an increase in the catalase activity was also observed, although less than for the treatment " $0 \_5$ ", signaling, in this case, the interruption of the phytotoxic action.

Oracz et al. (2007) reported increases in the catalase activity in Sinapis alba L. seeds subjected to Helianthus annuus L. extract up to eight days of germination, while Pandey et al. (2005) in Chara zeylanica and Lin et al. (2000) in Echinochloa crus-galli found a reduction in the catalase activity in plants subjected to allelopathic extract. Such differences may be explained by plant-specific mechanisms to scavenge the production of reactive oxygen species.

The activity of ascorbate peroxidase in seeds under normal germination conditions $\left(0 \% ; \mathrm{vv}^{-1}\right)$ remains stable during the phases I and II (up to $48 \mathrm{~h}$ ), gradually increasing during the seedling growth and development (Figure 5B). However, in seeds exposed to allelochemicals $\left(5 \%\right.$; $\left.\mathrm{vv}^{-1}\right)$, the levels of ascorbate peroxidase increase rapidly during the germination phases I and II (up to $48 \mathrm{~h}$ ) and decrease rapidly during the seedling growth and development phase (after $48 \mathrm{~h}$ ).

The increase and reduction in the levels of the ascorbate peroxidase enzyme, in seeds exposed to the extract, are possibly related to the metabolic response of production and action of the enzyme to neutralize the reactive oxygen species, accumulated by the phytotoxic effect of the extract. The treatments "0_5" and "5_0" did not present significant changes in the ascorbate peroxidase activity.

The results corroborate those by Pandey et al. (2005), who reported a reduced ascorbate peroxidase activity in C. zeylanica plants. Muscolo et al. (2001) reported that phenolic compounds such as vanillic, p-coumaric and p-hydroxybenzoic acids are able to inhibit the enzymatic activity in seedlings. These substances are present in leaves of $L$. camara (Yi et al. 2006, Mishra 2015).

It was observed that, during the phases I and II of germination (up to $48 \mathrm{~h}$ ), all treatments showed a rapid increase in the proline levels (Figure 6A). During the seedling growth and development (phase III), there was a reduction in the level of proline in the control seedlings (without stress). However, it is observed that the proline level remained high in the seedlings subjected to phytochemical stress. Higher levels of proline, during the phase III of germination, were also observed in the treatments that suffered stress, either only during the phase III (treatment "0_5") or just before it (treatment "5_0") (Figure 6A).

According to Singh \& Rao (2003), proline protects proteins from denaturing, what may explain the elevation and maintenance of high levels in stressed seedlings, as an attempt to defend seedlings against allelochemical damage. An increase in the proline content was also recorded in Triticum
A

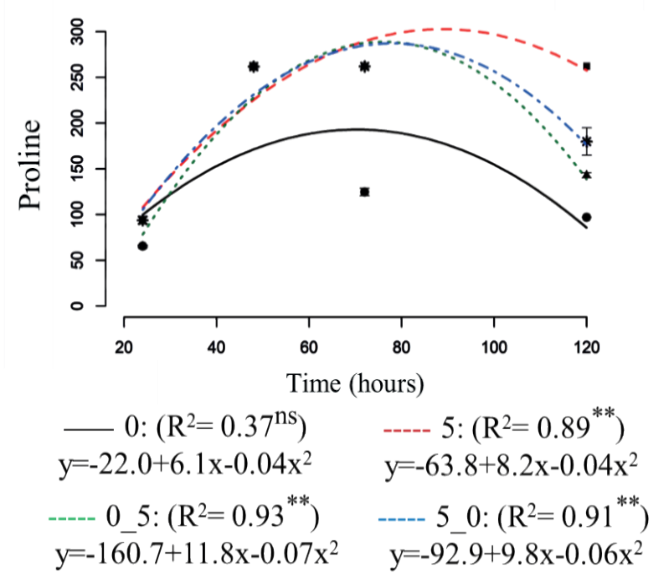

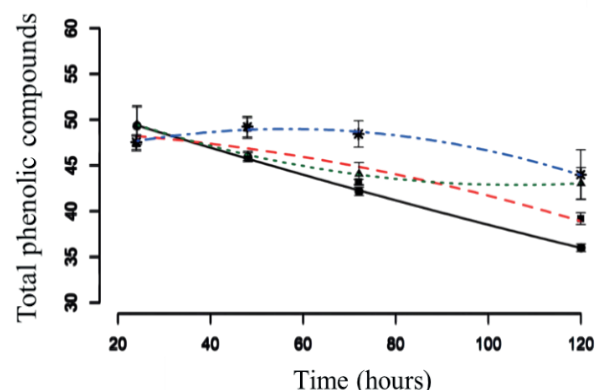

$$
\begin{array}{cc}
-0:\left(R^{2}=0.97^{* *}\right) & ---5:\left(R^{2}=0.83^{* *}\right) \\
y=53.3-0.2 x+0.0002 x^{2} & y=49.0-0.02 x-0.0006 x^{2} \\
0 \_5:\left(R^{2}=0.80^{* *}\right) & ---5 \_0:\left(R^{2}=0.67^{* *}\right) \\
y=53.8-0.2 x+0.001 x^{2} & y=44.9+0.1 x-0.01 x^{2}
\end{array}
$$

Figure 6. Regression for the contents of proline (A; $\mu \mathrm{mol} \mathrm{g}^{-1}$ of fresh mass) and total phenolic compounds [B; mg GAE (gallic acid equivalent] $\mathrm{g}^{-1}$ of fresh mass), during the germination period (in hours) of Avena sativa seeds, when kept in water (0) or exposed to Lantana camara extract at the concentration of $5 \%\left(\mathrm{vv}^{-1}\right)(5)$, and with induction $\left(0 \_5\right)$ or removal (5_0) of the phytotoxic stress. The bars for observed points are the mean standard deviations. 
turgidum and Pisum sativum, as a response to phytochemical coumarin (Abenavoli et al. 2006); Tagetes erecta under treatment with Jatropha curcas extract (Wang et al. 2009); and Triticum aestivum leaves with aqueous extract of Zea mays leaves (Ibrahim et al. 2013). After that, Ladhari et al. (2014) also reported an accumulation of proline in lettuce leaves, in response to the methanolic extract of Cleome arabica; however, this accumulation was reduced in the roots.

The levels of total phenolic compounds were reduced throughout the germination of seeds in all treatments; however, the levels remained higher than for the control in the treatments exposed to allelochemicals (Figure 6B). Djanaguiraman et al. (2005) reported that allelochemicals increase the phenolic content in Sorghum bicolor and Phaseoulus vulgaris. Ladhari et al. (2014) stated that allelochemicals increase the phenolic content in lettuce roots, but reduce it in lettuce leaves; while Pandey et al. (2005) reported a reduction in the phenolic content of $C$. zeylanica exposed to allelochemicals.

\section{CONCLUSION}

Concentrations of the aqueous extract of Lantana camara leaves above $2.5 \%\left(\mathrm{vv}^{-1}\right)$ impair the physiological development of Avena sativa seeds during germination. The extract affects the phases I and II of germination, damaging cellular membranes and delaying the radicle emission, and, at the phase III, it causes abnormalities in the seedling development. In addition, this phytotoxic effect triggers the enzymatic and non-enzymatic antioxidant metabolism of $A$. sativa seeds during germination. Hence, this study corroborates the potential of L. camara allelochemicals for the development of natural herbicides.

\section{ACKNOWLEDGMENTS}

The first author (D. M. Gindri) thanks the Companhia Integrada de Desenvolvimento Agrícola de Santa Catarina (CIDASC), for contributing to its Ph.D. in Crop Production, as well as the Universidade do Estado de Santa Catarina (UDESC), for providing research facilities; C. M. M. Coelho thanks the CNPq/Capes, for the research fellowships; and V. G. Uarrota thanks the FONDECYT-CONICYT (Project number 3190055) and the Vicerrectoria de Investigacion y Estudios Avanzados of the Pontificia Universidade Católica de Valparaiso, for research facilities.

\section{REFERENCES}

ABENAVOLI, M. R.; CACCO, G.; SORGONÀ, A.; MARABOTTINI, R.; PAOLACCI, A. R.; CIAFFI, M.; BADIANI, M. The inhibitory effects of coumarin on the germination of durum wheat (Triticum turgidum ssp. durum, cv. Simeto) seeds. Journal of Chemical Ecology, v. 32, n. 2, p. 489-506, 2006.

ABU-ROMMAN, S.; SHATNAWI, M.; SHIBLI, R. Allelopathic effects of spurge (Euphorbia hierosolymitana) on wheat (Triticum durum). American Eurasian Journal of Agricultural \& Environmental Sciences, v. 7, n. 3, p. 298-302, 2010.

ALEXIEVA, V.; SERGIEV, I.; MAPELLI, S.; KARANOV, E. The effect of drought and ultraviolet radiation on growth and stress markers in pea and wheat. Plant Cell Environment, v. 24, n. 12, p. 1337-1344, 2001.

AUMONDE, T.; MARTINAZZO, E.; PEDÓ, T.; BORELLA, J.; AMARANTE, L.; VILLELA, F. A.; MORAES, D. M. Respostas fisiológicas de sementes e plântulas de alface submetidas ao extrato de Philodendron bipinnatifidum. Semina: Ciências Agrárias, v. 34, n. 6, p. 3181-3192, 2013.

AZEVEDO, R. A.; ALAS, R. M.; SMITH, R. J. Response of antioxidant enzymes to transfer from elevated carbon dioxide to air and ozone fumigation, in the leaves and roots of wild-type and a catalase-deficient mutant of barley. Physiologia Plantarum, v. 104, n. 2, p. 280-292, 1998.

BATES, L. S.; WALDREN, R. P.; TEARE, I. D. Rapid determination of free proline for water stress studies. Plant and Soil, v. 39, n. 1, p. 205-207, 1973.

BEWLEY, J.; BRADFORD, K.; HILHORST, H.; NONOGAKI, H. Germination. In: BEWLEY, J.; BRADFORD, K.; HILHORST, H.; NONOGAKI, H. (ed.). Seeds: physiology of development, germination and dormancy. 3. ed. New York: Springer, 2013. p. 133-182.

BOGATEK, R.; GNIAZDOWAKA, A. ROS and phytohormons in plant-plant allelopathic interaction. Plant Signaling \& Behavior, v. 2, n. 4, p. 317-318, 2007.

BRADFORD, M. M. A rapid and sensitive method for the quantitation of microgram quantities of protein utilizing the principle of protein-dye binding. Analytical Biochemistry, v. 72, n. 1-2, p. 248-254, 1976.

CARDOSO, V. J. M. Germinação. In: KERBAUY, G. B. (ed.). Fisiologia vegetal. 2. ed. Rio de Janeiro: Guanabara Koogan, 2004. p. 386-407. 
CHENGXU, W.; MINGXING, Z.; XUHUI, C.; BO, Q. Review on allelopathy of exotic invasive plants. Procedia Engineering, v. 18, n. 1, p. 240-246, 2011.

DJANAGUIRAMAN, M.; PANDIYAN, M.; DEVI, D. D. Physiological responses of Eucalyptus globulus leaf leachate on seedling physiology of rice, sorghum and blackgram. International Journal of Agricultural and Biological Engineering, v. 7, n. 1, p. 35-38, 2005.

FOLIN, O.; CIOCALTEU, V. On tyrosine and tryptophane determinations in proteins. Journal of Biological Chemistry, v. 73, n. 2, p. 627-650, 1927.

GAWEL, S.; WARDAS, M.; NIEDWOROK, E.; WARDAS, P. Malondialdehyde (MDA) as a lipid peroxidation marker. Wiadomości Lekarskie, v. 57, n. 9-10, p. 453-455, 2004.

GINDRI, D. M.; COELHO, C. M. M.; UARROTA, V. G.; REBELO, A. M. Herbicidal bioactivity of natural compounds from Lantana camara on the germination and seedling growth of Bidens pilosa. Pesquisa Agropecuária Tropical, v. 50, e57746, 2020.

GMEREK, J.; POLITYCKA, B. Response of maize, pea and radish roots to allelochemical stress. Acta Biologica Cracoviensia Series Botanica, v. 53, n. 1, p. 32-37, 2011.

HADDADCHI, G. R.; GERIVANI, Z. Effects of phenolic extracts of canola (Brassica napuse L.) on germination and physiological responses of soybean (Glycin max L.) seedlings. International Journal of Plant Production, v. 3 , n. 1, p. 63-67, 2009.

HAMMOND-KOSACK, K. E.; JONES, J. D. G. Resistance gene-dependent plant defense responses. The Plant Cell, v. 10, n. 10, p. 1773-1791, 1996.

HEATH, R. L.; PACKER, L. Photoperoxidation in isolated chloroplasts: I. Kinetics and stoichiometry of fatty acid peroxidation. Archives in Biochemistry and Biophysics, v. 125, n. 1, p. 189-198, 1968.

HUSSAIN, M. I.; REIGOSA, M. J. Allelochemical stress inhibits growth, leaf water relations, PSII photochemistry, non-photochemical fluorescence quenching, and heat energy dissipation in three C3 perennial species. Journal of Experimental Botany, v. 62, n. 13, p. 4533-4545, 2011.

IBRAHIM, M.; AHMAD, N.; SHINWARI, Z. K.; BANO, A.; ULLAH, F. Allelopathic assessment of genetically modified and non-modified maize (Zea mays L.) on physiology of wheat (Triticum aestivum L.). Pakistan Journal of Botany, v. 45, n. 13, p. 235-240, 2013.

INTERNATIONAL ALLELOPATHY SOCIETY (IAS). World congress on allelopathy: a science for the future: book of abstracts. Cadiz: Universidad de Cadiz; International Allelopathy Society, 1996.
KEGGE, W.; PIERIK, R. Biogenic volatile organic compounds and plant competition. Trends in Plant Science, v. 15, n. 3, p. 126-132, 2010.

KENANY, E.; DARIER, S. Suppression effects of Lantana camara L. aqueous extracts on germination efficiency of Phalaris minor Retz. and Sorghum bicolor L. (Moench). Journal of Taibah University for Science, v. 7, n. 2, p. 64$71,2013$.

KUPIDLOWSKA, E.; DOBRZYNSKA, K.; PARYS, E.; ZOBEL, A. M. Effect of coumarin and xanthotoxin on mitochondrial structure, oxygen uptake, and succinate dehydrogenase activity in onion root cells. Journal of Chemical Ecology, v. 20, n. 10, p. 2471-2480, 1994.

KUREK, K.; PLITTA-MICHALAK, B.; RATAJCZAK, E. Reactive oxygen species as potential drivers of the seed aging process. Plants, v. 8, n. 6, p. 174-186, 2019.

LADHARI, A.; OMEZZINE, F.; HAOUALA, R. The impact of Tunisian Capparidaceae species on cytological, physiological and biochemical mechanisms in lettuce. South African Journal of Botany, v. 93, n. 1, p. 222-230, 2014.

LATIF, S.; CHIAPUSIO, G.; WESTON, L. A. Allelopathy and the role of allelochemicals in plant defence. In: BECARD, G. (ed.). Advances in botanical research. Wagga Wagga: Academic Press, 2017. p. 19-54.

LIN, W. X.; KIM, K. U.; SHIN, D. H. Rice allelopathic potential and its modes of action on barnyardgrass (Echinochloa crus-galli). Allelopathy Journal, v. 7, n. 2, p. 215-224, 2000 .

MISHRA, A. Allelopathic properties of Lantana camara. International Research Journal of Basic and Clinical Studies, v. 3, n. 1, p. 13-28, 2015.

MITTLER, R. ROS are good. Trends in Plant Science, v. 22, n. 1, p. 11-19, 2017.

MUSCOLO, A.; PANUCCIO, M. R.; SIDARI, M. The effect of phenols on respiratory enzymes in seed germination: respiratory enzyme activities during germination of Pinus laricio seeds treated with phenols extracted from different forest soils. Plant Growth Regulation, v. 35, n. 1, p. 31-35, 2001.

NAKAGAWA, J. Testes de vigor baseados no desempenho de plântulas. In: KRZYZANOWSKI, F. C.; VIEIRA, R. D.; FRANÇA NETO, J. B. (ed.). Vigor de sementes: conceitos e testes. 2. ed. Londrina: Abrates, 1999. p. 1-24.

NAKANO, Y.; ASADA, K. Hydrogen peroxide is scavenged by ascorbate-specific peroxidase in spinach chloroplasts. Plant Cell Physiology, v. 22, n. 5, p. 867$880,1981$.

ORACZ, K.; BAILLY, C.; GNIAZDOWSKA, A.; CÔME, D.; CORBINEAU, F.; BOGATEK, R. Induction of 
oxidative stress by sunflower phytotoxins in germinating mustard seeds. Journal of Chemical Ecology, v. 33, n. 2, p. 251-264, 2007.

PANDEY, D.; MISHRA, N.; SINGH, P. Relative phytotoxicity of hydroquinone on rice (Oryza sativa L.) and associated aquatic weed green musk chara (Chara zeylanica Willd.). Pesticide Biochemistry and Physiology, v. 83, n. 2-3, p. 82-96, 2005.

POONPAIBOONPIPAT, T.; PANGNAKORN, U.; SUVUNNAMEK, U.; TEERARAK, M.; CHAROENYING, P.; LAOSINWATTANA, C. Phytotoxic effects of essential oil from Cymbopogon citratus and its physiological mechanisms on barnyardgrass (Echinochloa crus-galli). Industrial Crops and Products, v. 41, n. 2, p. 403-407, 2013.

QIAN, H.; XU, X.; CHEN, W.; JIANG, H.; JIN, Y.; LIU, W.; FU, Z. Allelochemical stress causes oxidative damage and inhibition of photosynthesis in Chlorella vulgaris. Chemosphere, v. 75, n. 3, p. 368-375, 2009.

R CORE TEAM. $R$ : a language and environment for statistical computing. Vienna: R Foundation for Statistical Computing, 2019.

ROMAGNi, J. G.; ALlEN, S. N.; DAYAN, F. E. Allelopathic effects of volatile cineoles on two weedy plant species. Journal of Chemical Ecology, v. 26, n. 1, p. 303-313, 2000.

SINGH, D.; RAO, Y. B. Allelopathic evaluation of Andrograhis paniculata aqueous leachates on rice (Oryza sativa). Allelopathy Journal, v. 11, n. 1, p. 71-76, 2003.
SINGH, R. K.; TIWARI, B.; SHARMA, D. K.; SINGH, S. P. Comparative study of chemical composition of Lantana camara leaf, flower \& fruit essential oil. International Journal of Pharmaceutical and Chemical Sciences, v. 1, n. 1, p. 895-899, 2012.

SOUZA-FILHO, A.; GUILHON, G.; SANTOS, L. Metodologias empregadas em estudos de avaliação da atividade alelopática em condições de laboratório: revisão crítica. Planta Daninha, v. 28, n. 3, p. 689-697, 2010.

TOIVONEN, P. M. A.; HODGES, D. M. Abiotic stress in harvested fruits and vegetables. In: SHANKER, A. (ed.). Abiotic stress in plants: mechanisms and adaptations. Croatia: InTech, 2011. p. 39-58.

VIEIRA, R. D.; CARVALHO, N. M. Testes de vigor em sementes. Jaboticabal: Funep, 1994.

WANG, J. C.; WU, Y.; WANG, Q.; PENG, Y. L.; PAN, K. W.; LUO, P.; WU, N. Allelopathic effects of Jatropha curcas on marigold (Tagetes erecta L.). Allelopathy Journal, v. 24, n. 1, p. 123-130, 2009.

YI, Z.; ZHANG, M.; LING, B.; XU, D.; YE, J. Inhibitory effects of Lantana camara and its contained phenolic compounds in Eichhornia crassipes growth. Journal of Applied Ecology, v. 17, n. 9, p. 1637-1640, 2006.

YU, J.; YE, S.; ZHANG, M.; HU, W. Effects of root exudates and aqueous root extracts of cucumber (Cucumis sativus) and allelochemicals, on photosynthesis and antioxidant enzymes in cucumber. Biochemical Systematics and Ecology, v. 31, n. 2, p. 129-139, 2003. 